\title{
Impact of economic, environmental, and corporate social responsibility reporting on financial performance of UAE banks
}

\author{
Nejla Ould Daoud Ellili ${ }^{1}$ (D) $\cdot$ Haitham Nobanee ${ }^{1}$
}

Received: 17 October 2021 / Accepted: 17 February 2022 / Published online: 4 March 2022

(c) The Author(s), under exclusive licence to Springer Nature B.V. 2022

\begin{abstract}
This study investigates the degree of sustainability disclosure of listed banks in the UAE financial markets and analyzes the effect of sustainability disclosure on banking performance. Sustainability disclosure is examined by considering three dimensions-economic, environmental, and corporate social responsibility-and using content analysis. Dynamic panel regression was used to study the impact of sustainability disclosure on banking performance by differentiating between conventional and Islamic banks. The empirical results show that banks' levels of sustainability disclosure are low. Moreover, dynamic panel data reveal that sustainability disclosure has a positive and significant impact on bank performance. The results of this study assist the Central Bank of the UAE in developing a corporate sustainability disclosure framework to improve bank transparency, reduce information asymmetry, and improve compliance with sustainability standards.
\end{abstract}

Keywords Corporate sustainability disclosure $\cdot$ Economic disclosure $\cdot$ Environmental disclosure $\cdot$ Corporate social responsibility disclosure $\cdot$ Banking performance

JEL Classification C33 - G32 - G34

\section{Introduction}

Corporate sustainability has gained significant importance from corporations, stakeholders, academics, researchers, and policymakers. In the last two decades, there has been increasing pressure on listed companies to disclose corporate sustainability reports.

In the international context, the increase in awareness of the importance of sustainability efforts has been reflected in the creation of non-governmental organizations such as the Global Reporting Initiative (GRI), established in 1997 and released in 2000, the

Nejla Ould Daoud Ellili

nejla.ellili@adu.ac.ae

Haitham Nobanee

haitham.nobanee@adu.ac.ae

1 College of Business, Abu Dhabi University, P.O. Box 59911, Abu Dhabi, United Arab Emirates 
most well-known sustainability disclosure framework to assist companies in measuring and disclosing their economic, environmental, social, and governance performance. In fact, companies are advised to monitor their sustainability compliance to develop their strategies, enhance their performance, and assist investors in comprehending the relationship between sustainability efforts and corporate financial performance. To further improve the quality of sustainability disclosure, the International Integrated Reporting Council (IIRC) was formed in 2010 and released in 2013 its framework providing guidelines to companies about the integrated and effective report of financial and non-financial information. More recently, the Taskforce on Climate-Related Financial Disclosure (TCFD) was presented in 2017, its final report setting out recommendations to help corporations report climaterelated financial information and measure the potential financial implications of climatechange practices such as lower-carbon emissions, energy, and water efficiency solutions and sustainable land-use.

More specifically, in the context of the UAE, there is growing awareness of the importance of sustainability by developing national frameworks that guide companies to increase their reporting transparency and improve their sustainability performance through the adoption of sustainability initiatives. In the UAE, the primary legislation for environmental protection is Federal Law Number 24 of 1999 for the protection and development of the environment that sets out criminal and civil penalties for environmental offenses. In addition, sustainability efforts in the UAE have been reflected in the creation of several bodies such as the Emirates Environmental Group (1991), Emirates Green Building Council (2006), Dubai Supreme Council of Energy (2009), Dubai Carbon Center of Excellence (2011), and Dubai Sustainability Council (2015). All of these bodies are concerned with environmental protection, economic progress, and sustainable development in the UAE. Moreover, following the global economy that emerged from the COVID-19 pandemic, the importance of economic, environmental, and social risks has attracted more interest from policymakers due to their financial impacts, which would lead to profound adjustments to the economy. The UAE has already been included as a key goal in its Vision 2021, sustainable development emphasizing further on, among others, energy efficiency, compliance with corporate social responsibility, and an efficient waste of management. With regard to the statistics of the sustainability disclosure, the report by KPMG (2020) revealed that the percentage of UAE companies that disclosed the sustainability reports was $51 \%$ in 2020 and has risen from $44 \%$ in 2017. Despite this increase, this percentage remains lower than the global average of $77 \%$, and further efforts should be made within the UAE regarding this matter.

This study focuses on banks because of their key role in the UAE economy and their vital participation in sustainable economic growth. Despite the challenges faced by UAE banks during the COVID-19 pandemic, the financial sector is still considered a resilient sector that plays an active role in the UAE economy. In 2020, the total assets has expanded by $3.4 \%$, and the aggregate loans has grown by $1.2 \%$ (CBUAE, ${ }^{1} 2020$ ). In addition, the financial industry is one of the top contributors to the UAE's gross domestic product (GDP), with a contribution of $8 \%$ in 2019. In the UAE, the banking system consists of conventional and Islamic banks with a supportive regulator, the central bank. The Conventional bank activity is based on interest-earning activities and they accounts $81 \%$ of the total UAE banking assets, with a growth rate of total assets of $6.5 \%$ compared to $7.2 \%$

\footnotetext{
${ }^{1}$ Central Bank of the UAE.
} 
for the Islamic banks (CBUAE, 2020). According to the Islamic Financial Services Board (IFSB), the Islamic banking products in the UAE account $20 \%$ of the total banking products. The Islamic banking system complies with Islamic legal concepts and the Sharia rules. It is based on profit and loss sharing, and prohibits interest in charging. The significant impact of Islam on Islamic banks in the UAE suggests a strong basis for CSR practices. Islamic banks' practices are evidenced by Zakat, a religious requirement of donations to support financially specific categories of needy people, such as disabled, orphans, and widows, with the objective of ensuring a better society (Katsioloudes \& Brodtkorb, 2007). In the UAE, corporations are expected to satisfy the whole society as well as their own shareholders, and this needs a clear definition of CSR practices to improve the compliance of local and international companies operating in the UAE with social standards.

In the literature, there are many studies highlighting the importance of firms' sustainability disclosure such as continuous improvement (De Ron, 1998), the improvement of the management system (Daily \& Huang, 2001), the creation of financial value (Hart \& Milstein, 2003), the increase of transparency to stakeholders (Perrini \& Tencati, 2006), the motivation of staff (Jabbour \& Santos, 2008), the encouragement of innovation (Hansen et al., 2009, the attraction of long-term capital (Wehinger, 2011; Ernst \& Young, 2013), and the enhancement of corporate reputation (Lourenço et al., 2014; Michelon, 2011).

The importance of corporate disclosure has been discussed in many theories including agency theory (Jensen \& Meckling, 1976), signaling theory (Myers \& Majluf, 1984), stakeholder theory (Freeman, 1994), and legitimacy theory (Gray et al, 1995). Agency theory focuses on the conflict of interests between shareholders and managers, which may substantially affect firm performance (Jensen \& Meckling, 1976). According to this theory, to reduce agency problems, managers should provide relevant information to prove the alignment of their interests with those of shareholders (Healy \& Palepu, 2001). Signaling theory assumes that managers are more informed about the real value of the company than other investors; therefore, these managers may use this information asymmetry to their benefit and reinforce their entrenchment strategy in their respective companies (Myers \& Majluf, 1984). On the other hand, stakeholder theory discusses corporate responsibilities toward stakeholders. Based on this theory, firms are required to report all sustainability issues to preserve sustainable relationships with their stakeholders (Freeman, 1994). However, several empirical studies have addressed the importance of sustainability disclosures in the banking industry (Douglas et al., 2004; Khan et al., 2011; Hassan \& Harahap, 2010; Farook et al., 2011; Aribi \& Gao, 2012; Jain et al., 2015; Nobanee \& Ellili, 2016; and Islam \& Kokubu, 2018).

Studies have also examined possible influences on the degree of sustainability disclosure. Firms may disclose their sustainability information to compete with the government's environmental concerns (Liu \& Anbumozhi, 2010). Moreover, other factors may influence sustainability reporting, including the effect of corporate governance (Khan, 2011; Michelon \& Parbonetti; 2010; Zeng et al., 2010 and Nazari et al., 2015; Endrikat et al., 2021), stakeholders' power (Dong et al., 2014; Erlandsson \& Tillman, 2009; Lu \& Abeysekera, 2014), exposure to public pressure and transparency (García-Sánchez et al., 2013; Moseñe et al., 2013; Alcaraz-Quiles et al., 2014; and Dobler et al., 2015), and an increase in the company's efficiency and innovation (Nie \& Wang, 2019).

Stakeholder power is an important factor influencing environmental disclosure. In this context, Erlandsson and Tillman (2009) built a framework to investigate the drivers, barriers, and enablers of corporate environmental disclosure. The framework consisted of two parts. The first part relates to the types and classes of environmental information, while the second part relates to the different stakeholders of the company as an important factor 
influencing firms' environmental information management. However, Lu and Abeysekera (2014), considering 100 firms on the 2008 Chinese stock-listed firms' social responsibility ranking list, confirm that shareholders influence firms' social and environmental disclosures and that creditors influence firms' disclosures related to their environmental performance. These results support stakeholder theory and indicate that firms seeking to gain or maintain the support of powerful stakeholders should adopt appropriate disclosure strategies.

In the context of the UAE, there are only a few studies that examine sustainability disclosure in annual reports, and all confirm that most companies in the UAE comply with the UAE environmental laws (Katsioloudes \& Brodtkorb, 2007), social responsibility disclosure positively affects corporate financial profitability (Rettab et al., 2009), and the degree of environmental disclosure varies between Islamic and conventional banks (Nobanee \& Ellili, 2016). In the measure of sustainability disclosure, Nobanee and Ellili (2016) considered only energy and environmental items, while in the current study, sustainability disclosure is measured by all three dimensions of sustainability: economic, environmental, and social. Nobanee and Ellili (216) have employed the growth of short-term deposits as a measure of banking performance, while in this current study, banking performance is assessed by a more comprehensive measure, the return on equity (ROE), which indicates the overall bank's performance and reveals the profit generated from the stockholders' investment. None of the above-mentioned studies have investigated the impact of sustainability disclosure on banking performance by differentiating between Islamic and conventional banks, so this study will be the first to shed light on this topic.

The objective of this study is to explore longitudinal sustainability disclosure in the annual reports of UAE banks and examine the impact of sustainability disclosure on banking performance. The four main questions in the study are as follows: (1) To what extent do UAE listed banks disclose their sustainability matters? (2) What is the trend in longitudinal sustainability disclosure? (3) Are there any significant differences in sustainability disclosures between Islamic and conventional banks? (4) Is there any significant impact of sustainability disclosure on banking performance?

The findings of this study will be useful to UAE regulators in developing a framework for appropriate sustainability disclosure. This framework would improve the bank's transparency.

In this study, the degree of sustainability disclosure was measured by the content analysis of annual reports including the three sustainability dimensions, specifically economic, social, and environmental, and by comparing Islamic and conventional banks. Dynamic panel data regressions were used to analyze the impact of the degree of sustainability disclosure on the banking performance of Islamic and conventional banks listed on the UAE financial markets for 2003-2013.

The remainder of this paper is organized as follows. Section 2 presents a literature review on sustainability disclosure and its impact on financial performance. Section 3 presents the research methodology, Sect. 4 presents the empirical results, and Sect. 5 presents the conclusions. 


\section{Literature review}

\subsection{Sustainability disclosure in the banking sector}

In the literature, there are, on one side, several studies that have explored during only oneyear the sustainability disclosure (Hassan \& Harahap, 2010; Farook et al., 2011; Aribi \& Gao, 2012; Kiliç, 2016) while other studies have examined the longitudinal sustainability disclosure as an effort to highlight the development of the sustainability initiatives (Douglas et al., 2004; Islam \& Kokubu, 2018; Jain et al., 2015; Khan et al., 2011; Nobanee \& Ellili, 2016). All the above-mentioned studies relied on content analysis, and their findings showed a consensus among them about the positive trend in the volume of sustainability disclosure.

In the one-year studies, the papers of Hassan and Harahap (2010), Farook et al. (2011) Aribi and Gao (2012) have examined the cross-country sustainability disclosure status and the corporate social activities in the annual reports of Islamic banks operating in different countries. More specifically, Hassan and Harahap (2010) considered seven banks in seven different countries (Bahrain, Bangladesh, Indonesia, Malaysia, Saudi Arabia, Kuwait, and the United Arab Emirates), while Farook et al. (2011) used an expanded sample of 47 banks operating in 15 countries (Bahrain, Bangladesh, Egypt, Iran, Jordan, Kuwait, Malaysia, Pakistan, Qatar, Saudi Arabia, Sudan, Turkey, the United Arab Emirates, and Yemen). Aribi and Gao (2012) focused on the Gulf region and analyzed the influence of Islam on the CSR practices of 21 Islamic financial institutions. Hassan and Harahap (2010) and Farook et al. (2011) revealed that Islamic banks disclose sustainability and social information, but there is no consistency in their reporting and recommended that Islamic banks mandate the Shari'ah Supervisory board regulations to communicate their sustainability activities, gain more confidence in their stakeholders, and respond better to environmental pressure. Aribi and Gao (2012) showed that Islamic financial institutions disclose sustainability information in line with Islamic principles, confirming their compliance with Islamic ethics. In addition, as the Internet is considered one of the most important communication channels used by companies, Kiliç (2016) explored the online reporting practices of 25 Turkish banks by considering four dimensions: the environment and energy, human resources, products and customers, and community involvement. The empirical results reveal that the Turkish banks have, on average, an online disclosure index of $48.11 \%$, and some improvements in the sustainability disclosure remain needed, and the banks' management should improve their decision-making process to increase the awareness about environmental protection and energy conservation.

In the UAE, there are many initiatives undertaken by the government to increase the awareness about the importance of the sustainability activities within the companies and improves their compliance with the sustainability disclosure practice, we develop the following hypothesis:

H1 All conventional and Islamic banks disclose sustainability information in their annual reports and websites.

In longitudinal studies, and more particularly in the European context, Douglas et al. (2004) explored the extent of sustainability disclosure, considered as a total management quality tool, in the annual reports and websites of a sample of Irish banks during the period 1998-2001 and benchmarked it against the best practices of European banks. 
The empirical results show that there is a large discrepancy in the volume of sustainability information between annual reports and websites, showing much greater sustainability information on websites. In addition, the results revealed that despite the increase in the trend of the overall volume of Irish banks' sustainability information, this volume remains below the best practices of Europe. In a different institutional context, Khan et al. (2011) studied the trends in sustainability disclosure of 12 major commercial banks in Bangladesh in comparison with the GRI framework during 2008-2009. More recently and in the same context, Islam and Kokubu (2018) examined also the longitudinal CSR disclosure of Bangladeshi banking industry from the legitimacy theory perspective. They analyze the contents of the annual reports of all listed banks on the Dhaka Stock Exchange during the period 2004-2013. Using a CSR index, the empirical findings show an increase in CSR disclosure from 20 in 2004 to 60 in 2013, which demonstrates that banks respond better to legitimate requirements with society's expectations about environmental initiatives.

In a broader Asian context, Jain et al. (2015) analyzed the annual reports and websites of large banks from different Asia-Pacific countries (Japan, China, Australia, and India) during the period 2005-2011 by using a disclosure framework including environmental indicators, among others. Their empirical results show that CSR disclosure continues to expand at both the quality and quantity levels on a voluntary basis. In terms of international comparison, Australian banks have the highest quality and transparency of CSR disclosure as they are more involved in social responsibility policies.

According to all the above studies, there is a consensus that conventional and Islamic banks disclose their sustainability information in their annual reports and websites, but the volume of the information remains lower than the stakeholders' expectations. In addition, they show a positive trend in the sustainability disclosure of banks over time. In addition, the UAE is one of the top economies open to foreign direct investment (FDI). According to the UAE's Economic Report (2019), the UAE is ranked first in the Arab world and second in the West Asia region in terms of percentages of the total FDI inflows at $36 \%$ and $35.5 \%$, respectively. It is necessary that UAE banks align with this openness strategy and show higher compliance with international sustainability disclosure practices. Hence, the following hypothesis is proposed:

H2 The volume of sustainability information in banks' annual reports and/or websites increases over time.

In the comparison between Islamic and conventional banks, Sobhani et al.'s (2012) study was the first to explore the extent of sustainability disclosures in the annual reports and websites of 29 banks listed on Bangladeshi stock exchanges by differentiating between Islamic and conventional banks. They measure economic, environmental, and social disclosures and find that Islamic banks disclose more sustainability information in both annual reports and websites than do conventional banks. More recently, Nobanee and Ellili (2016) explored the degree of sustainability disclosure in the annual reports of all UAE banks during the period 2003-2013. The empirical results show that overall sustainability disclosure is at a very low level, and Islamic banks have lower sustainability disclosure levels than conventional banks. This result is explained by the fact that conventional banks have higher leverage and more financial constraints than Islamic banks do. In addition, Islamic financial institutions are already in full compliance with Islamic principles and ethics and are under less pressure with regard to 
disclosure transparency, while conventional banks must be more responsive to the pressure of stakeholders and governments for environmental and social reporting. The third hypothesis is as follows.

H3 The conventional banks disclose more sustainability information than Islamic banks.

\subsection{Sustainability disclosure and corporate performance}

The impact of sustainability initiatives on corporate performance has been examined through theoretical and empirical studies. In the theoretical literature, Nie et al. (2019) developed a model to examine the impact of the integration of both environmental responsibility and social concerns into the business operations on the corporate profit. By comparing the CSR focused company (CSR) and profit maximization focused company (PM), the model indicates that environmental responsibility has a positive impact on the profit of the PM company, while the impact is negative for the CSR company. This result indicates that the responsible behavior of a company toward the environment increases its stock price, and this effect is smaller for companies with high levels of CSR prices. In addition, the model reveals a loss for the PM company owing to social concerns, while the results related to the CSR company remain uncertain.

In the empirical literature, there is no consensus among studies examining the impact of sustainability disclosures on financial performance. For instance, Carnevale and Mazzuca (2014) and Wang (2016) revealed a positive impact, whereas Nobanee and Ellili (2016) found it to be non-significant.

Considering the effect of corporate governance, Wang (2016) investigated the impact of environmental disclosure on the financial performance of 756 companies listed on the Taiwan Stock Exchange in 2010. The empirical results of the content analysis and Ohlson valuation model indicate a significant positive impact of environmental disclosure on financial performance. Moreover, corporate governance is positively correlated with environmental disclosure, suggesting that good governance enhances the quality of corporate disclosure and reduces information asymmetry between investors and company management. Similarly, Endrikat et al. (2021) indicated through the application of several meta-analytical techniques that the board of directors' characteristics (size, independence, and diversity) are positively associated with CSR disclosure. This result confirms agency theory predictions and states that the board of directors is an effective corporate governance mechanism.

By tackling banks, Carnevale and Mazzuca (2014) test the direct effect of sustainability disclosure on the stock price of 176 European banks during 2002-2011. The empirical results show that sustainability disclosures are positively correlated with stock prices and indicate that investors appreciate the additional and complementary information offered by banks' sustainability disclosures in an effort to reduce information asymmetry. Moreover, the cross-country analysis shows that the relevance of sustainability reports varies across European countries owing to the influence of the institutional context.

Contrary to previous studies, Nobanee and Ellili (2016) find a non-significant impact of sustainability disclosure on the performance of Islamic and conventional banks. This might be because sustainability disclosure has been measured solely by the environmental and energy dimensions, while in the current study, sustainability is measured by a more comprehensive index that includes economic and social matters in addition to environmental and energy information. The latter two dimensions are of high interest to the shareholders and stakeholders of different banks. This interest is even higher following the different initiatives undertaken 
Table 1 List and type of the UAE banks

\begin{tabular}{lll}
\hline List & Bank name & Type \\
\hline 1 & Abu Dhabi Commercial Bank & Conventional \\
2 & Bank of Sharjah & Conventional \\
3 & Abu Dhabi Islamic Bank & Islamic \\
4 & Dubai Islamic Bank & Islamic \\
5 & Emirates Islamic Bank & Islamic \\
6 & Sharjah Islamic Bank & Islamic \\
7 & Commercial Bank of Dubai & Conventional \\
8 & Commercial Bank International & Conventional \\
9 & NBD Emirates & Conventional \\
10 & Union National Bank & Conventional \\
11 & RAK Bank & Conventional \\
12 & Mashreq Bank & Conventional \\
13 & First Gulf bank & Conventional \\
14 & United Arab Bank & Conventional \\
15 & National Bank of Abu Dhabi & Conventional \\
16 & National Bank of Umm Al-Quwain & Conventional \\
\hline
\end{tabular}

by UAE policymakers and financial regulators to increase awareness about the importance of sustainability, environmental protection, and social responsibility. Thus, the fourth hypothesis is as follows:

H4 There is an impact of the sustainability disclosure on banking performance.

All of the above-mentioned studies considered only one direction in the investigation of the impact of sustainability disclosure on financial performance. Waddock and Graves (1997) and Weber (2017) considered bi-directional in this relationship. In particular, Waddock and Graves (1997) explored the possible link between financial performance and corporate social disclosure in 469 companies from the S\&P 500. Their results showed that good financial performance is associated with high sustainability disclosure, confirming that companies with low financial performance find it difficult to make discretionary investments related to sustainability and corporate social responsibility, while companies with high financial performance are more able to invest in these long-term strategic projects. In addition, Weber (2017) analyzes the relationship between sustainability reporting and financial performance by exploring the annual reports and websites of Chinese banks, as well as the effect of the Chinese Green Credit Policy. Using panel data and Granger causality, Weber (2017) finds that the environmental and social reporting of Chinese banks increased significantly between 2009 and 2013. Moreover, the empirical results reveal bidirectional causality between sustainability disclosure and banking performance, with a stronger impact in the direction of financial performance on sustainability disclosure. 


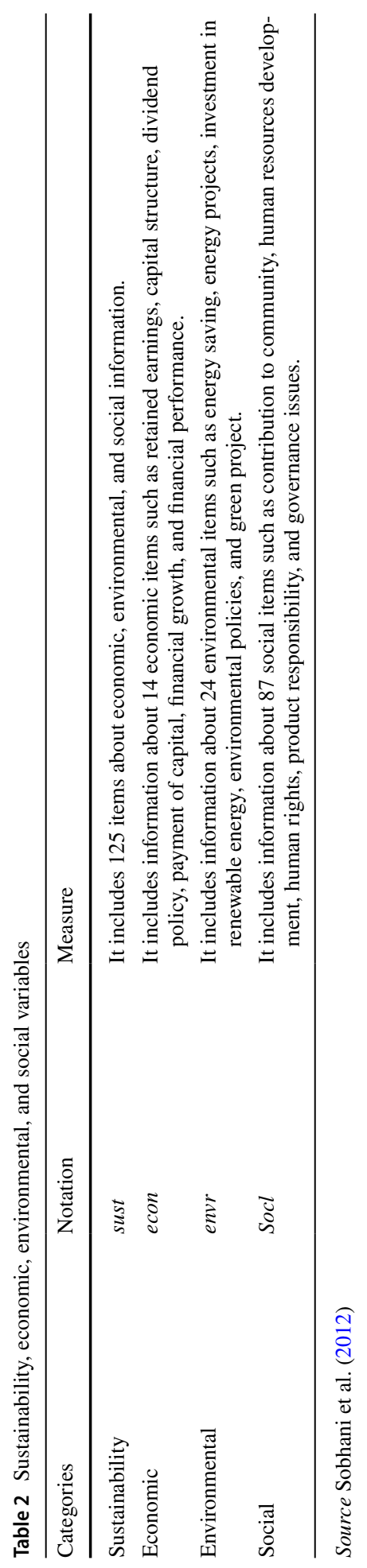


Table 3 Average levels of corporate sustainability disclosure of UAE banks

\begin{tabular}{llll}
\hline Mean & Full sample & Conventional banks & Islamic banks \\
\hline Overall disclosures & .2696355 & .2821373 & .2364071 \\
Environmental disclosures & .0271654 & .0252747 & .0319444 \\
Economic disclosures & .4739011 & .4642857 & .5097403 \\
Social disclosures & .3444627 & .3705282 & .2817645 \\
\hline
\end{tabular}

Table 4 Mann-Whitney test of corporate sustainability disclosure indices for all UAE banks, conventional and Islamic

\begin{tabular}{lllll}
\hline Mann-Whitney test & Overall disclosure & $\begin{array}{l}\text { Environmental dis- } \\
\text { closures }\end{array}$ & Economic disclosures & Social disclosures \\
\hline Coefficient & 1.560 & -0.129 & -0.518 & $2.913^{*}$ \\
\hline
\end{tabular}

*Significant at the $95 \%$ confidence level

\section{Research methodology}

The aim of this study is to measure the extent of economic, social, and environmental sustainability disclosures in the annual reports of all listed banks in the UAE financial markets. Second, this study examines the potential effect of economic, social, and environmental sustainability disclosures on UAE banks' profitability from 2003 to 2013. Our sample includes 16 banks (12 conventional banks and 4 Islamic banks) (Table 1).

In this study, sustainability disclosure is measured according to the index developed by Sobhani et al. (2012) and based on economic, environmental, and social categories. Banking performance is measured by the growth in interest income (Table 2).

\subsection{Content analysis}

Content analysis is used to measure the overall sustainability disclosure index as well as the separate indices of economic, social, and environmental disclosures in banks' annual reports. The construction procedure starts by computing the sum of the scores of the items in each category and then dividing these sum scores by the number of items in each category. Then, the sum of the scores is divided by the total number of items in all categories for all UAE listed banks as well as separately for conventional and Islamic banks. The index values ranged from 0 to $100 \%$. A value of $0 \%$ means no disclosure by the bank, whereas a value of $100 \%$ means full disclosure. To compare the degree of disclosure between Islamic and conventional banks, Table 3 reports the means of the overall sustainability disclosure index as well as the means of each category for all conventional and Islamic banks. In addition, we ran a Mann-Whitney test to examine any significant differences in sustainability disclosures between Islamic and conventional banks, and the results are reported in Table 4. 


\subsection{Dynamic panel data}

To estimate the impact of the extent of overall sustainability disclosure as well as economic, social, and environmental disclosures on banking profitability, we employ the generalized method of moment system estimation applied to the dynamic panel data suggested by Arellano and Bover (1995) and Blundell and Bond (1998) and its finite sample correction proposed by Windmeijer (2005). This estimation has been used to consider the dynamic structure between the dependent and independent variables (Baltagi, 1995). Furthermore, this estimation technique controls for missing or unobserved variables and relationships (Arellano-Bond, 1991; Matyas \& Sevestre, 1996). The use of dynamic panel analysis also allows dynamic effects to be incorporated into the model and feedback from current and past shocks (Gocer et al., 2014; Hsiao, 1986). An important feature of this estimation is that it controls for possible endogeneity and unobservable heterogeneity by allowing some explanatory variables to be jointly determined with the dependent variables. We employ this technique for all UAE banks.

The dynamic panel data methods lead to the following equation:

$$
g i i_{i t}=\alpha+\beta_{1} g_{i i_{t_{-1}}}+\beta_{2} \text { tbe }_{i t_{-1}}+\beta_{3} \lg \operatorname{ta}_{i t_{-1}}+\beta_{4} \text { sust }_{i t_{-1}}+\beta_{5} \text { econ }_{i t_{-1}}+\beta_{6} \text { socl }_{i t_{-1}}+\beta_{7} \text { envr }_{i t_{-1}}+\varepsilon_{i t}
$$

The $\left(g i i_{i t}\right)$ is the first difference in the growth of interest income, $\left(g i i_{i t_{-}}\right)$is the differenced lagged dependent variable, $\left(t b e_{i t_{-1}}\right)$ is a control variable of leverage measured by the first difference of total borrowing to equity, $\left(\lg t a_{i t_{-1}}\right)$ is the control variable of size measured by the first difference of the logarithm of total assets, $\left(\right.$ sust $\left._{i t}\right)$ is the first difference in the degree of overall sustainability disclosure, $\left(e n v r_{i t}\right)$ is the first difference in the degree of environmental disclosure, $\left(e^{20 n_{i t}}\right)$ is the first difference in the degree of economic disclosure, $\left(\operatorname{socl}_{i t}\right)$ is the first difference in the degree of social disclosure, and $\left(\varepsilon_{i t}\right)$ is the error term.

\section{Results and discussion}

The estimation descriptive results regarding overall sustainability, economic, social, and environmental disclosures of all UAE banks and Islamic and conventional banks are reported in Table 3, which presents the means of the overall sustainability disclosure index, the environmental disclosure index, the economic disclosure index, and the social disclosure index for all banks and, separately, for conventional and Islamic banks. The averages of the overall sustainability disclosure indices are as follows: $26.9 \%$ for all banks, $28 \%$ for conventional banks, and $23.6 \%$ for Islamic banks. The results indicate that the overall sustainability disclosure of UAE banks was low. This result confirms our first hypothesis that states that all banks disclose their sustainability matters and reflects the further efforts of the UAE in increasing awareness about sustainability. In addition, the results reveal that conventional banks have higher levels of overall sustainability disclosure and social disclosure than Islamic banks. However, Islamic banks have higher environmental and economic disclosure levels than conventional banks do. These results partially confirm the third hypothesis, which states that conventional banks have higher sustainability disclosures than Islamic banks do, while the results show that conventional banks have only higher social disclosure. This could be explained by the fact that Islamic banks are already compliant 


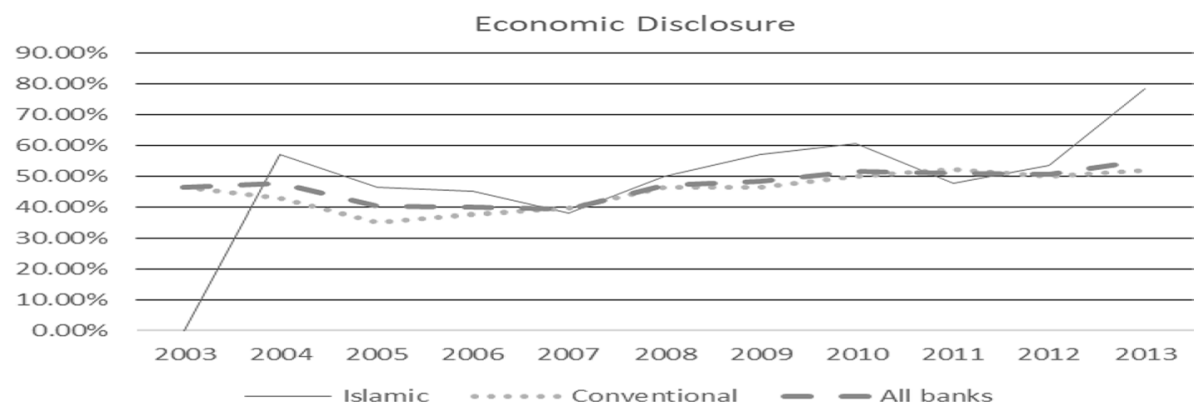

Fig. 1 Trend in the economic disclosure for Islamic, conventional, and all banks

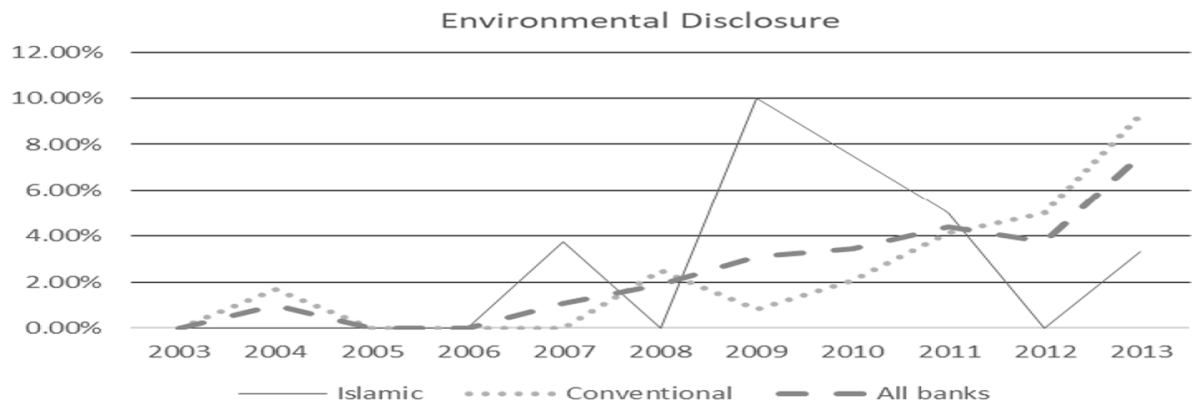

Fig. 2 Trend in the environmental disclosure for Islamic, conventional, and all banks

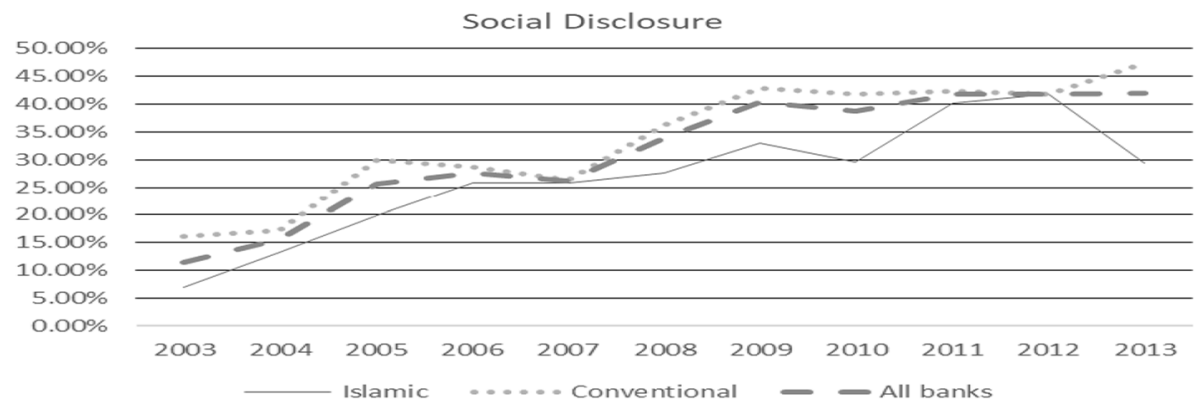

Fig. 3 Trend in the social disclosure for Islamic, conventional, and all banks

with Islamic principles and have already gained the trust of their stakeholders with regard to social matters, while conventional banks need to make more efforts to fill the gap of trust in their social commitments.

Figures 1, 2, 3, and 4 show the trend in the disclosure of economic, social, and environmental disclosures, as well as the overall disclosure of Islamic, conventional, and all UAE banks. The average of all disclosure indices of all banks in the UAE increased from 2003 to 2013. More particularly, the Economic disclosure has increased from $46.43 \%$ in 2003 to $55.36 \%$ in 2013 , the environmental disclosure from 0 to $7.5 \%$, the social disclosure $11.94 \%$ to $41.95 \%$, and overall sustainability from 12.40 to $29.53 \%$. 


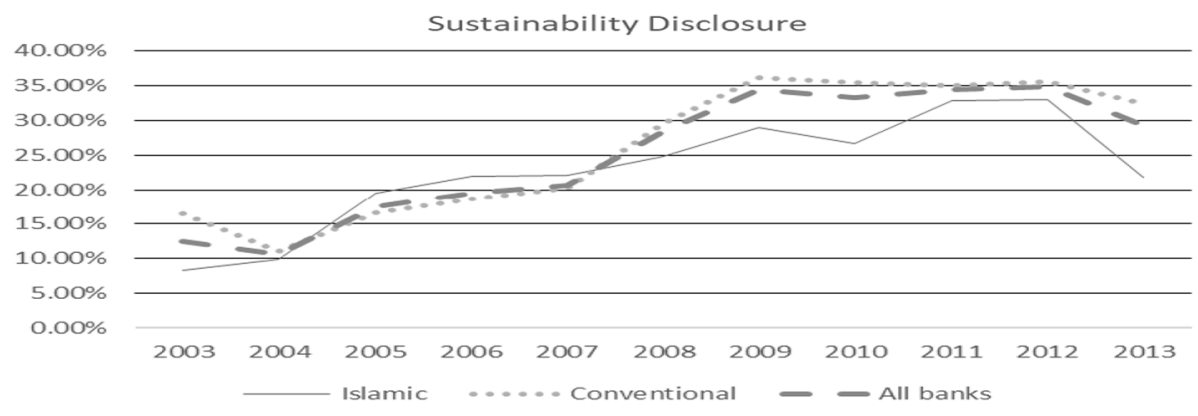

Fig. 4 Trend in the sustainability disclosure for Islamic, conventional, and all banks

With regard to Islamic banks, the sustainability disclosure has gradually increased from 2003 to 2012, and the most important increase is at the level of the economic index, which has risen from $0 \%$ in 2003 to $78.57 \%$ in 2013 . The same trend was observed for the conventional banks, with the most remarkable increase in the social disclosure, from $16.09 \%$ in 2003 to $47.29 \%$ in 2013. This result confirms the second Hypothesis that states that there is a positive trend in sustainability disclosure. This is strong evidence of the interest of all banks in improving their disclosure transparency and reporting high compliance with sustainability matters. However, Islamic banks disclose more environmental information, which corroborates the findings of Sobhani et al. (2012). Through this disclosure, Islamic banks make efforts to keep their stakeholders updated about their latest investments in green technologies to avoid negative impacts on the environment.

The results of the Mann-Whitney test reported in Table 4 reveal no significant differences in the levels of overall sustainability discloser environmental disclosure or economic disclosures between Islamic and conventional banks. The results confirm that the levels of social disclosure differ significantly between conventional and Islamic banks.

Table 5 reports the results of the dynamic panel data two-step system GMM estimation of the relationship between the levels of overall sustainability, environmental, economic, and social disclosures, and the bank performance of all banks. The results of the lagged dependent variable indicate that bank performance in the previous period had a negative and significant effect on bank performance in the current period, which can be interpreted by the structural changes that occurred in the banking sector after the 2008 financial crisis. Following the crises, many large banks moved away from trading and cross-border activities that enhanced profitability before the crisis; however, moving away from such activities may reduce bank profitability after the crisis (Dudley, 2018). Leverage and size do not affect bank performance. The results show a significant and positive impact of social sustainability disclosure on bank performance and an insignificant impact of overall, environmental, and economic sustainability on bank performance. Economic and environmental disclosure indices do not affect banks' performance as when banks enforce the guidelines and frameworks of economic and environmental sustainability, this might be associated with higher costs and may have an insignificant or negative relationship with profitability. This partially confirms the fourth hypothesis, which states that sustainability disclosure has a positive impact on corporate performance, while the results indicate that only social disclosure has a significant impact on banking performance, while the other types of disclosures have no significant impact. This result contradicts those of Nobanee and Ellili (2016) and shows that stakeholders have a high awareness of the importance of banks' compliance 
Table 5 Results of the dynamic panel data two-step GMM system estimation of the overall sustainability, environmental, economic, and social disclosure indices

\begin{tabular}{llll}
\hline Dependent: performance & Coefficient & Standard Error & Z-Value \\
\hline Lag dependent & -0.670775 & 0.0342518 & $-19.58^{* *}$ \\
Overall Sustainability Disclosure Index & 1.7483630 & 2.9033070 & 0.6000 \\
Environmental Disclosure Index & -2.263157 & 1.8244810 & -1.240 \\
Social Disclosure Index & -6.547204 & 2.0534540 & $-3.190^{* *}$ \\
Economic Disclosure Index & -1.810750 & 1.8620510 & -0.970 \\
Leverage & -.2772827 & 0.1599978 & -1.730 \\
Size & 0.6898601 & 0.3956056 & 1.7400 \\
\hline Diagnostic checking & & Z/Chi2 & Prob \\
\hline Arellano-Bond test for AR(1) in First Differences & 1.10 & 0.270 \\
Arellano-Bond test for AR(2) in First Differences & & -0.91 & 0.364 \\
Sargan Test of Overid. Restrictions & & 23.94 & 0.523 \\
Hansen test of Overid. Restrictions & & & 1.000 \\
\hline
\end{tabular}

${ }^{* *}$ Significant at the $99 \%$ confidence level

with social matters and a big interest in being updated about the efforts of banks in respecting social standards.

\section{Conclusion}

In this study, we measure the extent of overall sustainability and economic, social, and environmental disclosures and investigate their effects on banks' profitability for listed banks in the Dubai and Abu Dhabi financial markets during the period 2003-2013. The results reveal insignificant differences in overall sustainability and economic and environmental disclosures between Islamic and conventional banks, whereas social disclosures are significantly higher in the annual reports of conventional banks. This may indicate that conventional banks disclose more social matters to show a higher level of social responsibility in their activities as well as a higher level of consideration of moral and ethical principles in their business. In addition, the results of the dynamic panel data reveal that sustainability, economic, and environmental disclosures have no significant effects on the banking performance of all UAE banks and that social disclosures have significant and positive effects on bank performance. This result may indicate that since the banks in the UAE are still starting their sustainability reporting, the benefits of compliance with sustainability standards would be sufficient to offset the costs of the banks' environmental and social initiatives.

The results of this study offer UAE banks an investigation regarding the level of overall sustainability and economic, social, and environmental disclosures, and assist the UAE Central Bank in developing a corporate sustainability disclosure context and the necessary guidelines to improve the bank's transparency, reduce information asymmetry, and improve compliance with sustainability standards. Nowadays, stakeholders and the government are 
not only concerned with corporate financial performance but also with corporate innovations and efforts with respect to the adoption of sustainability policies.

\section{References}

Alcaraz-Quiles, F. J., Navarro-Galera, A. D., \& Ortiz-Rodríguez, A. O. (2014). Factors influencing the transparency of sustainability information in regional governments: An empirical study. Journal of Cleaner Production, 82, 179-191.

Arellano, M., \& Bond, S. (1991). Some test of specification of panel data: Monte Carlo evidence and an application to employment equations. Review of Economic Studies, 58, 277-297.

Arellano, M., \& Bover, O. (1995). Another look at the instrumental variable estimation of error component models. Journal of Econometrics, 68, 29-51.

Aribi, Z. A., \& Gao, S. S. (2012). Narrative disclosure of corporate social responsibility in Islamic financial institutions. Managerial Auditing Journal, 27, 199-222.

Dudley, W.C. (2018) 'Structural changes in banking after the crisis', Committee on the Global Financial System, Bank for International Settlements, Basel, Switzerland, https://www.bis.org/publ/cgfs60. pdf.

Baltagi, B. H. (1995). Econometric analysis of panel data. Wiley.

Blundell, R., \& Bond, S. (1998). Initial conditions and moment restrictions in dynamic panel data models. Journal of Econometrics, 87, 115-143.

Carnevale, C., \& Mazzuca, M. (2014). Sustainability report and bank valuation: Evidence from European stock markets. Business Ethics: A European Review, 23(1), 69-90.

Central Bank of the UAE. (2020). Financial stability report. Retrieved December 27, 2021, from https:// centralbank.ae/sites/default/files/2021-06/2020\%20FSR\%20Report\%20EN.pdf

De Ron, A. J. (1998). Sustainable production: The ultimate result of a continuous improvement. International Journal of Production Economics, 56, 99-110.

Dobler, M., Lajili, K., \& Zeghal, D. (2015). Corporate environmental sustainability disclosures and environmental risk: Alternative tests of socio-political theories. Journal of Accounting and Organizational Change, 10, 301-332.

Dong, S., Burritt, R., \& Qian, W. (2014). Salient stakeholders in corporate social responsibility reporting by Chinese mining and minerals companies. Journal of Cleaner Production, 84, 59-69.

Douglas, A., Doris, J., \& Johnson, B. (2004). Corporate social reporting in Irish financial institutions. The Total Quality Management Magazine, 16(6), 387-395.

Endrikat, J., De Villiers, C., Guenther, T. W., \& Guenther, E. M. (2021). Board characteristics and corporate social responsibility: A meta-analytic investigation. Business and Society, 60(8), 2099-2135.

Erlandsson, J., \& Tillman, A. M. (2009). Analyzing influencing factors of corporate environmental information collection, management and communication. Journal of Cleaner Production, 17, 800-810.

Ernst, Y. L. L. P. (2013). The Value of Sustainability Reporting. Center for Corporate Citizenship.

Farook, S., Hassan, M. K., \& Lanis, R. (2011). Determinants of corporate social responsibility disclosure: The case of Islamic banks. Journal of Islamic Accounting and Business Research, 2, 114-141.

Freeman, R. E. (1994). The politics of stakeholder theory. Business Ethics Quarterly, 4, 409-421.

García-Sánchez, I. M., Frías-Aceituno, J. V., \& Rodríguez-Domínguez, L. (2013). Determinants of corporate social disclosure in Spanish local governments. Journal of Cleaner Production, 39, 60-72.

Gocer, I., Mercan, M., \& Peker, O. (2014). Effect of foreign direct investments on the domestic investments of developing countries: A dynamic panel data analysis. Journal of Economic and Social Studies, 4, 69-85.

Gray, R., Kouhy, R., \& Lavers, S. (1995). Corporate social and environmental reporting: A review and a longitudinal study of UK disclosure. Accounting, Auditing and Accountability Journal, 8, 47-77.

Hansen, E. G., Grosse-Dunker, F., \& Reichwald, R. (2009). Sustainability innovation cube- a framework to evaluate sustainability-oriented. International Journal of Innovation Management, 13, 683-713.

Hart, S. L., \& Milstein, M. B. (2003). Creating sustainable value. Academy of Management Executive, $17,56-67$.

Hassan, A., \& Harahap, S. S. (2010). Exploring corporate social responsibility disclosure: The case of Islamic banks. International Journal of Islamic and Middle Eastern Finance and Management, 3, 203-227.

Healy, P., \& Palepu, K. (2001). Information asymmetry, corporate disclosure, and the capital markets: A review of the empirical disclosure literature. Journal of Accounting and Economics, 31, 405-440.

Hsiao, C. (1986). Analysis of panel data. Cambridge University Press. 
Jain, A., Keneley, M., \& Thomson, D. (2015). Voluntary CSR disclosure works: Evidence from AsiaPacific banks. Social Responsibility Journal, 11, 2-18.

Islam, M. T., \& Kokubu, K. (2018). "Corporate social reporting and legitimacy in banking: A longitudinal study in the developing country'. Social Responsibility Journal, 14(1), 159-179.

Jabbour, C. J. C., \& Santos, F. C. A. (2008). Relationships between human resources dimensions and environmental management in companies: Proposal of a model. Journal of Cleaner Production, 16(1), 51-58.

Jensen, M., \& Meckling, W. (1976). Theory of the firm: Managerial behavior, agency costs, and capital structure. Journal of Financial Economics, 3, 305-360.

Katsioloudes, M. I., \& Brodtkorb, T. (2007). Corporate social responsibility: An exploratory study in the United Arab Emirates. SAM Advancement Management Journal, 72(4), 9-20.

Khan, M. H. Z., Islam, M. A., Fatima, J. K., \& Ahmed, K. (2011). Corporate sustainability reporting of major commercial banks in line with GRI: Bangladesh evidence. Social Responsibility Journal, 7(3), $347-362$.

Kiliç, M. (2016). Online corporate social responsibility (CSR) disclosure in the banking industry: Evidence from Turkey. International Journal of Bank Marketing, 34(4), 550-569.

KPMG. (2020) The KPMG survey of sustainability reporting 2020. Retrieved December 27, 2021, from https://assets.kpmg/content/dam/kpmg/xx/pdf/2020/11/the-time-has-come.pdf

Liu, X., \& Anbumozhi, V. (2010). Determinant factors of corporate environmental information disclosure: An empirical study of Chinese listed companies. Journal of Cleaner Production, 17, 593-600.

Lourenço, I. C., Callen, J. L., Branco, M. C., \& Curto, J. D. (2014). The value relevance of reputation for sustainability leadership. Journal of Business Ethics, 119, 17-28.

Lu, Y., \& Abeysekera, I. (2014). Stakeholders' power, corporate characteristics, and social and environmental disclosure: Evidence from China. Journal of Cleaner Production, 64, 426-436.

Matyas, L., \& Sevestre, P. (1996). The econometrics of panel data (2nd ed.). Kluwer Academic Publishers.

Michelon, G. (2011). Sustainability disclosure and reputation. Corporate Reputation Review, 14, 79-96.

Michelo, G., \& Parbonetti, A. (2010). The effects of corporate governance on sustainability disclosure. Journal of Management Governance, 16(3), 477-509.

Moseñe, J. A., Burritt, R. L., Sanagustín, M. V., Moneva, J. M., \& Tingey-Holoyak, J. (2013). Environmental reporting in the Spanish wind energy sector: An institutional view. Journal of Cleaner Production, 40, 199-211.

Myers, S. C., \& Majluf, N. (1984). Corporate financing and investment decisions when firms have information that investors do not have. Journal of Financial Economics, 13, 187-221.

Nazari, J. A., Herremans, I. M., \& Warsame, H. A. (2015). Sustainability reporting: External motivators and internal facilitators. Corporate Governance, 15, 375-390.

Nie, P. Y., \& Wang, C. (2019). An analysis of cost-reduction innovation under capacity constrained inputs. Applied Economics, 51(6), 564-576.

Nie, P. Y., Wang, C., \& Meng, Y. (2019). An analysis of environmental corporate social responsibility. Managerial and Decision Economics, 40(4), 384-393.

Nobanee, H., \& Ellili, N. (2016). Corporate sustainability disclosure in annual reports: Evidence from UAE banks: Islamic versus conventional. Renewable and Sustainable Energy Reviews, 55, 1336-1341.

Perrini, F., \& Tencati, A. (2006). Sustainability and stakeholder management: The need for new corporate performance evaluation and reporting systems. Business Strategy and the Environment, 15, 296-308.

Rettab, B., Brik, A. B., \& Mellahi, K. A. (2009). Study of management perceptions of impact of corporate social responsibility on organizational performance in emerging economic: A case of Dubai. Journal of Business Ethics, 89, 371-390.

Sobhani, F. A., Amran, A., \& Zainuddin, Y. (2012). Sustainability disclosure in annual reports and websites: A study of the banking industry in Bangladesh. Journal of Cleaner Production, 23, 75-85.

Taskforce on Climate-Related Financial Disclosures. (2017). Recommendations of the taskforce on climaterelated financial disclosure. Retrieved March 29, 2018, from https://www.fsb-tcfd.org/wp-content/ uploads/2017/06/FINAL-TCFD-Report-062817.pdf

UAE's Economic Report. (2019). Retrieved December 28, 2021, from https://www.economy.gov.ae/Econo micalReportsEn/MOE_Annual\%20Economic\%20Report_2019_.pdf

Waddok, S. A., \& Graves, S. B. (1997). The corporate social performance-financial performance link. Strategic Management Journal, 18(4), 303-319.

Wang, M. C. (2016). The relationship between environmental information disclosure and firm valuation: The role of corporate governance. Quality and Quantity, 50(3), 1135-1161.

Weber, O. (2017). Corporate sustainability and financial performance of Chinese banks. Sustainability Accounting Management and Policy Journal, 8(3), 358-385. 
Wehinger, G. (2011). Fostering long-term investment and economic growth: Summary of a high-level OECD financial roundtable. OECD Journal: Financial Market Trends, 1, 1-21.

Windmeijer, F. (2005). A Finite sample correction for the variance of linear efficient two-step GMM estimators. Journal of Econometrics, 126, 25-51.

World Business Council for Sustainable Development. (2002). Sustainable development reporting: Striking the balance. World Business Council for Sustainable Development.

Zeng, S. X., Xu, X. D., Dong, Z. Y., \& Tam, V. W. Y. (2010). Towards corporate environmental information disclosure: An empirical study in China. Journal of Cleaner Production, 18, 1142-1148.

Publisher's Note Springer Nature remains neutral with regard to jurisdictional claims in published maps and institutional affiliations. 